\title{
Interleukin-8 expression in Helicobacter pylori infected, normal, and neoplastic gastroduodenal
}

\section{mucosa}

\author{
J E Crabtree, J I Wyatt, L K Trejdosiewicz, P Peichl, P H Nichols, N Ramsay, \\ J N Primrose, I J D Lindley
}

\begin{abstract}
Aims-To investigate the expression of interleukin-8 (IL-8) in Helicobacter pylori infected normal and neoplastic gastroduodenal mucosa, and in established gastric cancer cell lines.
\end{abstract}

Methods-Immunofluorescence techniques were used to localise IL-8 in cryosections of gastric $(n=25)$ and duodenal $(n=17)$ endoscopic biopsy specimens and in resected gastric tumour tissue samples from 16 patients. Two gastric cancer cell lines (Kato 3 and MKN 45) were examined for IL-8 protein expression by immunofluorescence and for the presence of IL-8 mRNA by reverse transcription followed by the polymerase chain reaction (RT-PCR). Results-IL-8 was localised to the epithelium in histologically normal gastric mucosa, with particularly strong expression in the surface cells. IL-8 expression was also a feature of surface epithelium in the duodenal bulb, but was much reduced in the second part of the duodenum. In chronic $H$ pylori-associated gastritis gastric epithelial IL-8 expression was increased and expression of IL-8 within the lamina propria was evident. By contrast, large areas of IL-8 negative epithelium were observed in the body mucosa of a subject with Ménétrier's disease. In gastric carcinoma the tumour cells were positive for IL-8. IL-8 was also detected by immunofluorescence in unstimulated Kato 3 and MKN 45 cells, and constitutive IL-8 gene expression in these cell lines was confirmed by detection of IL-8 mRNA by RT-PCR.

Conclusions-Immunoreactive IL-8, a potent neutrophil chemotactic and activating factor, is present in the epithelium of both normal and inflamed gastric mucosa with increased expression in the latter. There is site dependent variation in epithelial IL-8 expression within the gastroduodenal mucosa. The expression of the pro-inflammatory cytokine IL-8 in gastric carcinoma cells may influence peritumoural cellular infiltrates.

$(\mathfrak{F}$ Clin Pathol 1994;47:61-66)

Interleukin 8 (IL-8), also known as human neutrophil activating peptide (NAP-1), is a potent neutrophil chemotactic and activating peptide. ${ }^{1-5}$ It is produced by a variety of cell types, including monocytes, fibroblasts, endothelial and epithelial cells following in vitro stimulation with lipopolysaccharide or the cytokines IL-1 $\beta$ and tumour necrosis factor. ${ }^{45}$ Increased local synthesis of IL-8 occurs in several inflammatory conditions associated with polymorph infiltration such as psoriasis, ${ }^{6}$ ulcerative colitis, ${ }^{7}$ and rheumatoid arthritis. ${ }^{8-10}$ In vivo administration of IL-8 also induces neutrophil accumulation in animals. ${ }^{11}$ IL-8 may therefore be an important inducer of the immunopathological consequences of neutrophil infiltration.

There is increasing evidence to suggest that neutrophils have an important role in the development of peptic ulceration in both Helicobacter pylori-associated ulcers ${ }^{1213}$ and ulceration caused by non-steroidal anti-inflammatory drugs in experimental models. ${ }^{1415}$ The mucosal infiltration of polymorphs and associated release of toxic metabolites and lysosomal enzymes ${ }^{16}$ may be responsible for tissue damage and ulcer generation. Recent organ culture studies have shown high concentrations of gastric mucosal IL-8 secretion from antral biopsy specimens in patients with $H$ pylori infection and intraepithelial neutrophil infiltration (active gastritis). ${ }^{17}$ In vitro IL-8 secretion was also observed in most patients with histologically normal mucosa, suggesting constitutive IL-8 expression in gastric mucosa in the absence of $H$ pylori infection. The cellular source(s) of gastric IL-8 has not been identified.

This study aimed to localise immunohistologically the cellular origin of IL-8 in normal and $H$ pylori infected gastroduodenal mucosa. As some tumour cell lines secrete chemotactic factors ${ }^{1819}$ and express IL-8 following cytokine stimulation, ${ }^{20-24}$ we examined gastric carcinoma in vivo and gastric cancer cell lines for IL-8 protein and gene expression.

\section{Methods}

Gastroduodenal biopsy specimens from patients undergoing upper gastrointestinal endoscopy were obtained from the gastric antrum $(n=20)$, gastric corpus $(n=5)$, duodenal bulb $(n=9)$ and second part of the duodenum $(n=8)$ for immunohistological examination. Additional antral biopsy specimens were taken to examine urease activity using the "CLOtest" (Delta West Ltd, Bentley, Australia). Informed consent was obtained from all patients and the project was approved by the Clinical Research (Ethics) 
Committee of the Leeds Eastern Health Authority. These were not the same patients as those studied before. ${ }^{17}$

Freshly resected specimens of tumour and non-neoplastic tissue samples were obtained from 16 patients undergoing resection for gastric cancer, including one patient with Ménétrier's disease. All tissues were collected into Histocon (Cellpath plc, Hemel Hempstead, Herts), orientated on cork, coated in OCT compound (Miles Laboratories Inc, Naperville, Illinois), and snap frozen in thawing isopentane. Cryostat sections $(5 \mu \mathrm{m})$ were air dried, fixed in acetone, and stored at $-70^{\circ} \mathrm{C}$.

Cryostat sections stained with haematoxylin and eosin were examined by one histopathologist (JIW) for assessment of gastritis according to the Sydney system..$^{25}$ The gastric carcinomas were typed as intestinal or diffuse according to the Lauren classification. ${ }^{26}$

Single and double label indirect immunofluorescence were performed as described before. ${ }^{2728}$ Briefly, tissue sections were incubated with murine monoclonal antibody 4G9/A5/A7 to IL-8 (Sandoz Research Institute, Vienna) followed by absorbed fluorescein isothiocyanate (FITC) conjugated goat anti-mouse IgG (Southern Biotechnology Associates, Birmingham, Alabama, USA). Antibody 4G9/A5/A7 has been characterised in previous studies and shown not to cross react with other related peptides. ${ }^{829}$ For negative controls, the primary antibody was omitted or an irrelevant monoclonal antibody was used. The specificity of immunolabelling was shown by the abolition of immunolabelling after coincubation of the IL-8 monoclonal antibody with recombinant IL-8 (Sandoz Research Institute). ${ }^{2}$ For some experiments, a rabbit antibody raised against recombinant IL- 8 and tested for specificity by ELISA was used to confirm immunolabelling patterns (the kind gift of Dr R Banks). The presence of $H$ pylori was determined using a rabbit antibody raised against recombinant $H$ pylori urease $^{30}$ (a kind gift of Dr C Clayton) followed by tetraethylrhodamine isothiocyanate (TRITC) conjugated goat anti-rabbit Ig (Tago Inc, Burlingame, California, USA).

Double labelled immunofluorescence was used to identify infiltrating carcinoma cells in cryostat sections. Sections were incubated with murine IL-8 monoclonal antibody and either a rabbit polyclonal anti-keratin antibody (L14) or a rabbit anti-fibronectin antibody (L9), ${ }^{27}$ followed by fluorescein isothiocyanate (FITC) conjugated goat antimouse IgG and a TRITC-conjugated goat anti-rabbit immunoglobulin Murine monoclonal antibody LdS103, specific for cytokeratins of non-stratified epithelia, ${ }^{28}$ was also used to localise carcinoma cells. A rabbit anti-factor VIII antibody (Dako, High Wycombe, Bucks) was used to identify vascular endothelium. Sections were aqueous mounted and examined using a Zeiss Axioplan microscope fitted with epifluorescent illumination and selective filters for
FITC and TRITC.

Kato 3 (European Collection of Animal Cell Cultures, Salisbury, Wilts) ${ }^{31}$ and MKN $45^{32}$ human gastric cancer cell lines were grown in RPMI 1640 (ICN-Flow Laboratories, High Wycombe, Bucks) containing $10 \%$ fetal calf serum (Sera Lab, Crawley, Surrey) and $40 \mu \mathrm{g} / \mathrm{ml}$ gentamicin. Cytospin preparations or cell monolayers were fixed in acetone and immunolabelled for IL-8 and cytokeratin as above.

Total cellular RNA was extracted from 1 $\times 10^{6}$ Kato 3 and MKN 45 cells using a modification of Sambrook et al. ${ }^{33}$ Briefly, the pelleted cells were resuspended in $800 \mu \mathrm{l}$ of lysis buffer (4M guinidinium thiocyanate, 25 $\mathrm{mM}$ sodium citrate, $100 \mu \mathrm{M}$ 2-mercaptoethanol, $0.5 \%$ sodium lauroyl sarcosine), and the lysate centrifuged through a $5 \cdot 7 \mathrm{M}$ $\mathrm{CsCl}$ cushion at $100000 \mathrm{rpm}$ in a Beckmann Ti $100 \cdot 2$ rotor for 2.5 hours. After ethanol precipitation the RNA was suspended in 20 $\mu \mathrm{l} \mathrm{H}_{2} \mathrm{O}$, and $5 \mu \mathrm{l}$ was converted into first strand cDNA using the Stratagene First Strand Kit (Stratagene, La Jolla, California). Ten per cent of the resulting cDNA-RNA hybrid was used for each PCR determination, with 35 cycles of $72^{\circ} \mathrm{C}$ for 2 minutes; $91^{\circ} \mathrm{C}$ for 30 seconds; $55^{\circ} \mathrm{C}$ for 1 minute, followed by a final elongation step of $72^{\circ} \mathrm{C}$ for $10 \mathrm{~min}$ utes.

Polymerase chain reaction (PCR) amplification for IL-8 was performed with a 17$\operatorname{mer}\left(5^{\prime}\right.$-AAGGAACCATCTCACTG-3') and a 20-mer(5'-GATTCTTGGATACCACAGAG-3'), yielding a product of 352 base pairs. The PCR products were separated by electrophoresis on a $1.4 \%$ agarose gel, stained with ethidium bromide and the bands visualised on an ultraviolet transilluminator.

\section{Results}

IL-8 EXPRESSION IN NORMAL AND $H$ PYLORI INFECTED GASTRODUODENAL MUCOSA

IL-8 expression was observed in the gastric epithelia of all patients. The reactivity of monoclonal antibody 4G9/A5/A7 was abolished by absorption with recombinant IL-8. The rabbit anti-IL8 antibody showed an identical immunolocalisation pattern on all sections tested.

The seven histologically normal antral

Immunoreactivity of IL-8 in gastroduodenal epithelia and carcinoma

\begin{tabular}{llll}
\hline & $n=$ & $\begin{array}{l}\text { Surface } \\
\text { epithelium }\end{array}$ & $\begin{array}{l}\text { Crypt } \\
\text { epithelium }\end{array}$ \\
\hline $\begin{array}{llll}\text { Gastric antrum } \\
\quad \text { Normal }\end{array}$ & 7 & + & $\pm /-$ \\
$\quad \begin{array}{l}\text { Reactive gastritis } \\
\text { Chronic gastritis }\end{array}$ & 1 & ++ & + \\
$\begin{array}{l}\text { Gastric corpus } \\
\text { Normal }\end{array}$ & 12 & +++ & ++ \\
$\quad$ Chronic gastritis & 3 & + & $\pm /-$ \\
$\begin{array}{l}\text { Duodenum } \\
\text { Bulb }\end{array}$ & 9 & +++ & + \\
$\quad$ Second part & 8 & \pm+ & $++/+$ \\
Gastric cancer & 16 & & + \\
\hline
\end{tabular}

Immunofluorescence reactivity was scored subjectively from +++ (strong) to + (weak but unequivocal); fading into negativity has been indicated by $a \pm$. 

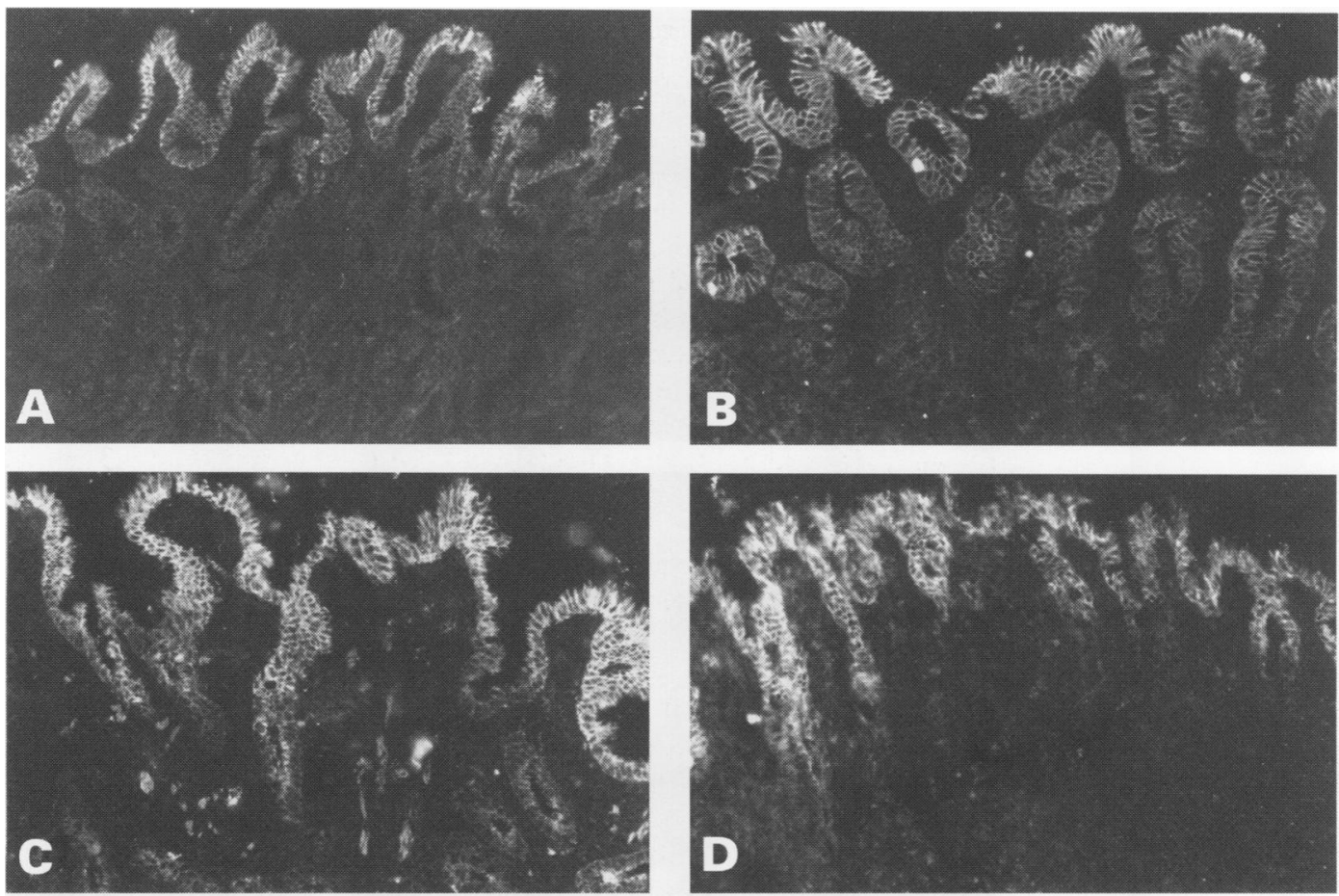

Figure 1 Immunofluorescent localisation patterns of IL-8 on cryostat sections of stomach in histologically normal, $H$ pylori negative antral $(A)$ and corpus (B) mucosa and in $H$ pylori positive biopsy specimens of antrum (C) and corpus (D) of patients with chronic gastritis.

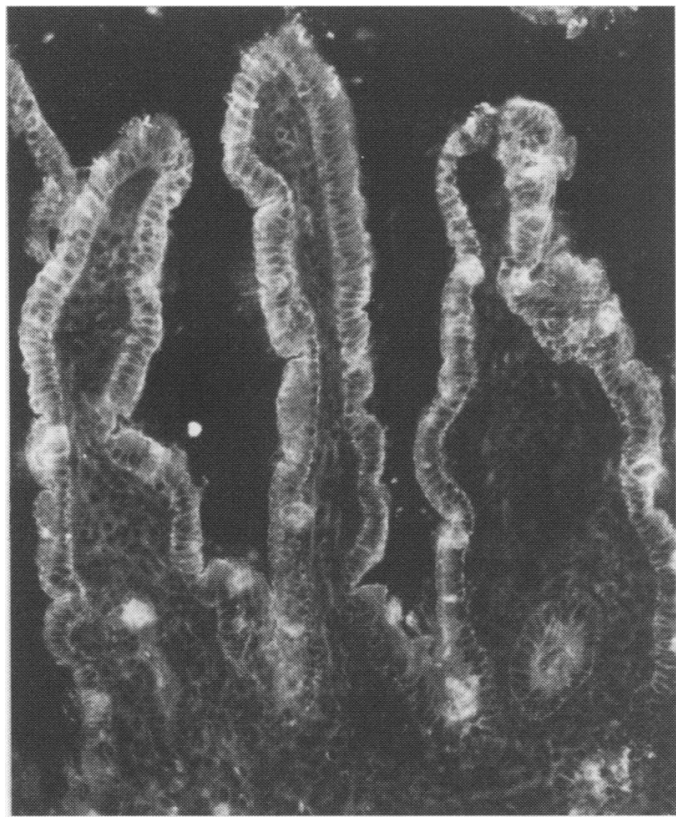
histologically normal duodenal bulb mucosa.

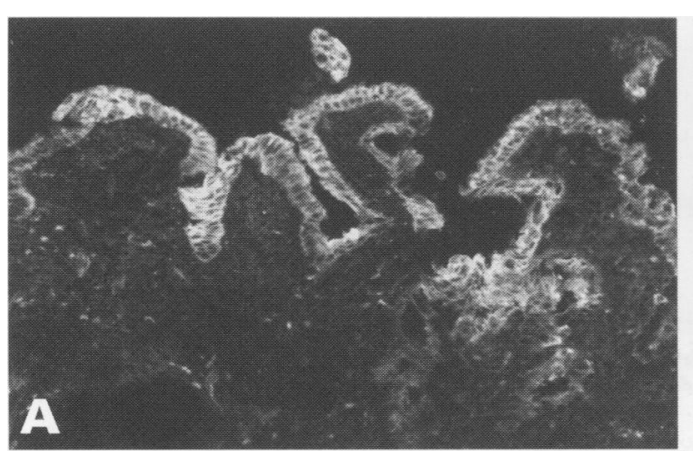

Figure 2 Immunofluorescent localisation of IL-8 in

biopsy specimens were all negative for $H$ pylori both immunohistologically and by the biopsy urease test. In these patients the strongest IL-8 immunolabelling was found in the surface epithelial cells, tending to localise along the lateral membranes of epithelial cells. Immunolabelling by epithelial crypt cells was more variable and weaker (table). There was minimal IL-8 immunolabelling within the lamina propria of normal gastric mucosa (fig 1A). Similar IL-8 expression patterns were observed in histologically normal, $H$ pylori negative biopsy specimens of gastric corpus mucosa (fig 1B).

All patients with chronic gastritis, whether superficial or atrophic, and the subject with reactive gastritis showed strong positivity for IL-8 in the gastric epithelium. In all cases the reactivity was stronger than in the histologically normal mucosa (table; figs 1C and $\mathrm{D}$ ). Fourteen of these 15 patients with chronic gastritis were positive for $H$ pylori by immunohistology and/or the CLOtest. Additional IL-8 immunolabelling was evident in the lamina propria in chronic gas-

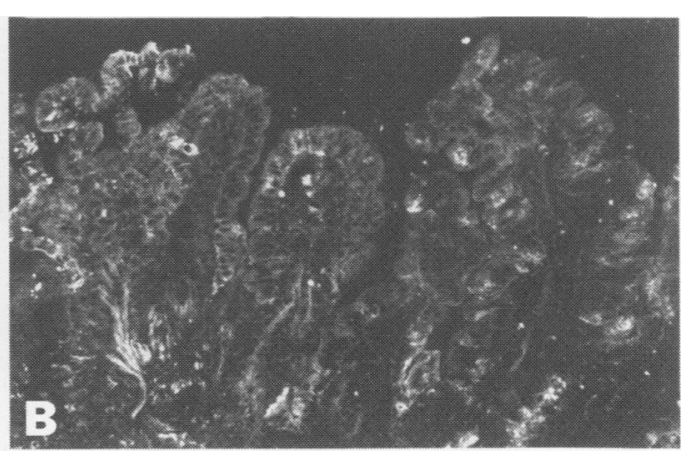

Figure 3 Comparison of IL-8 immunolocalisation in first part $(A)$ and second part $(B)$ of the duodenal mucosa in the same patient; this patient has duodenitis in the first part of the duodenum. Note the virtual absence of epithelial IL-8 expression in $(B)$. 
Figure 4 IL-8

immunolocalisation in gastric tumour cells. $I L-8$ localisation in crysotat sections of resected tumours illustrates expression by diffuse type $(A)$, intestinaltype $(B)$, and unclassified (C) gastric

adenocarcinomas. IL-8 was also detectable in the gastric carcinoma-derived Kato 3 cell line (D).
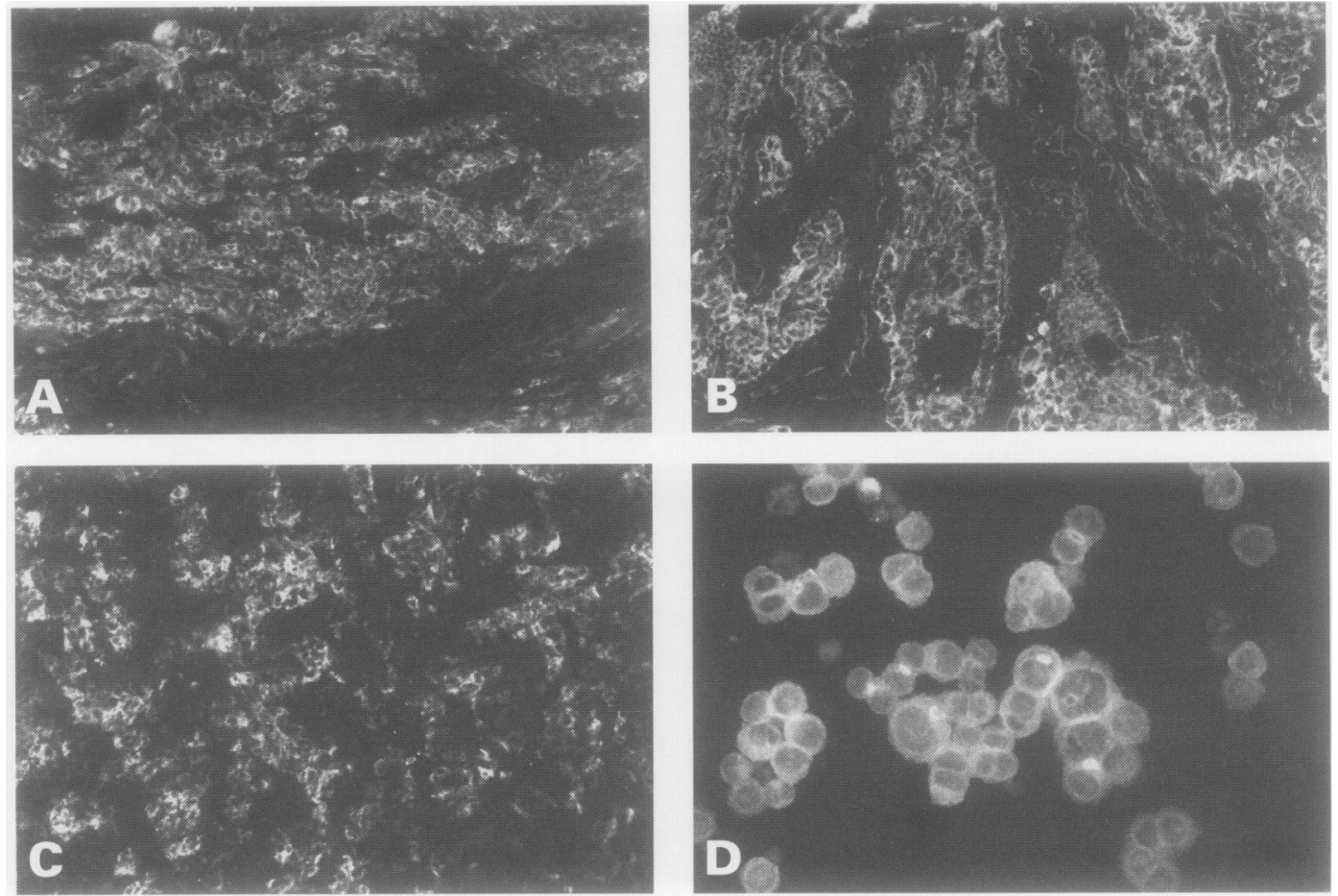

tritis, both in the lymphoid follicles and in some lamina propria cells (fig 1C). Muscle fibres within the lamina propria were also weakly labelled for IL-8 (fig 1C). Double immunofluorescence for IL-8 and factor VIII demonstrated no specific IL-8 immunolabelling in the vascular endothelium.

The epithelium of the duodenal bulb mucosa was IL-8 positive in all seven patients with normal histology (fig 2) and the two patients with duodenitis (fig 3A). In biopsy specimens from the second part of the duodenum the epithelium showed reduced (three patients) or essentially no reaction for IL-8 (five patients). Comparative analysis of duodenal biopsy specimens from the first and second parts from the same patients in three cases (figs $3 \mathrm{~A}$ and $\mathrm{B}$ ) confirmed the reduced IL-8 epithelial expression distally in the duodenum (table).

IL-8 IN GASTRIC CARCINOMA

Strong IL-8 expression was observed in the neoplastic cells of all 16 patients with gastric carcinoma (table). IL-8 expression in diffusetype $(n=6)$ and intestinal-type gastric cancer $(n=8)$ was equally positive (figs $4 A$ and $B$ ). Strong IL-8 expression was also observed in one subject with a mixed tumour type and one unclassified gastric carcinoma (fig 4C). Double labelled immunofluorescence showed that all cytokeratin positive, fibronectin negative carcinoma cells infiltrating the stroma were IL-8 positive.

In the patient with Ménétrier's disease the corpus mucosa (not the tumour) showed very areas the epithelium of the hyperplastic folds was negative for IL-8, but occasional small foci of positive epithelial cells were observed. The epithelium of the antral mucosa of this

IL-8 IN GASTRIC CARCINOMA CELL LINES

Using immunofluorescence, both gastric cancer cell lines were positive for cytokeratin. variable epithelial expression of IL-8. In some subject was positive for IL-8.

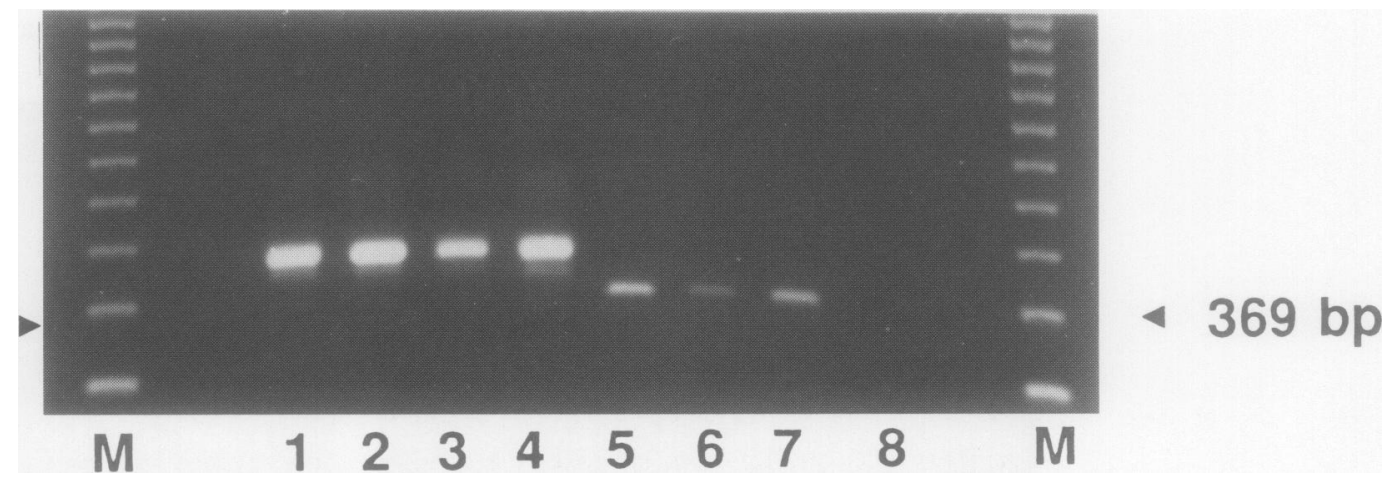

Figure $5 \quad P C R$ analysis of $m R N A$ from gastric carcinoma cell lines: PCR was performed as described in the text, using $\beta$ actin primers (lanes 1-4) and IL-8 primers lanes 5-8) on material from Kato 3 cells (lanes 1 and 5); MKN 45 cells (2 and 6); fresh peripheral blood mononuclear cells (3 and 7); and unstimulated $\mathrm{HaCaT}$ cells (4 and 8). The position of the third band (369 base pairs) from the 123 base pair ladder (Gibco-BRL) is indicated in lane $M$. 
Kato 3 (fig 4D) and MKN45 immunolabelled strongly for IL-8. PCR analysis of RNA extracted from MKN 45 and Kato 3 cells showed constitutive expression of IL-8 mRNA (fig 5). RNA was prepared from $10^{6}$ cells and first strand cDNA produced. PCR was then run using specific $\beta$ actin primers (lanes 1-4) and IL-8 primers (lanes 5-8). Also shown are results from fresh peripheral blood mononuclear cells as positive controls, and unstimulated $\mathrm{HaCaT}$ keratinocyte cells as negative controls.

\section{Discussion}

The surface epithelium of normal gastric mucosa is IL-8 positive and epithelial expression is increased in $H$ pylori-associated chronic gastritis. Gastric epithelial IL-8 expression was not dependent on the luminal location of cells as gastric carcinoma cells in the stroma were also IL-8 positive. The constitutive expression of IL-8 mRNA in gastric cancer cell lines supports these immunohistological observations on IL-8 expression in gastric epithelium. Only the patient with Ménétrier's disease seemed to have large regions of IL-8 negative epithelium in the gastric corpus mucosa. In this latter condition the hyperproliferation of the gastric epithelium may account for the focal lack of expression. This observation is of interest as it proves that gastric epithelial IL-8 expression is not invariably present.

Previous studies on cultured cells have shown signal specificity for induction of IL-8 gene expression. TNF $a$ and IL- $1 \beta$, but not lipopolysaccharide (LPS), induce IL-8 expression in pulmonary, ${ }^{21}$ renal, and transitional cell carcinoma ${ }^{20}$ cell lines and hepatoma cells. ${ }^{34}$ Gastric cancer cell lines have also recently been shown to secrete IL-8 in response to IL-1 $a$ and TNF $a{ }^{24}$ The local production of TNF $a$ by gastric mucosa in $H$ pylori infection ${ }^{35}$ may be responsible for increased epithelial IL-8 expression. $H$ pylori induction of TNF $\alpha$ and IL-1 $\beta$ from peripheral blood monocytes, which is independent and dependent on LPS, has been described. ${ }^{36}$

There is currently little information on IL-8 expression in normal or neoplastic human epithelium in vivo. Our data suggest a regional variation in epithelial IL-8 expression in the gastrointestinal tract, with the surface epithelium of gastric mucosa and duodenal bulb being strongly positive. The presence of IL-8 mRNA in unstimulated gastric cancer cell lines suggests that the in vivo IL-8 expression observed in $H$ pylori negative normal gastric epithelium may be constitutive. Exogenously induced expression cannot be excluded, however. The gastroduodenal mucosa may be exposed to bacterial products (such as LPS) from proximal sites (the oral cavity) and any cytokines induced by oral flora. Such factors may be directly or indirectly responsible for inducing IL-8 expression in normal gastroduodenal epithelium in the absence of $H$ pylori infection. The reduced expression of IL-8 in the epithelium of the second part of the duodenum is there- fore of interest, and whether the expression changes in inflammatory enteropathies is currently under investigation.

High concentrations of IL-8 are secreted by histologically normal gastric mucosa during in vitro culture ${ }^{17}$ and the current study suggests that the secreted IL-8 originates predominantly from the epithelium. The gastric juice of subjects with normal mucosa has recently been shown to have neutrophil chemotactic activity and there were increased concentrations in patients with moderate and severe gastritis. ${ }^{37}$ The identity of the chemotactic factor was not determined but as patients with normal mucosa would not be $H$ pylori positive, this activity could not be attributable to $H$ pylori derived neutrophil chemotactic factors such as formyl-methionylleucyl-phenylalanine (FMLP), ${ }^{38}$ the urease enzyme, ${ }^{39}$ platelet activating factor ${ }^{40}$ or other recently described chemotactic factors. ${ }^{41}{ }^{42}$ If continually secreted by the gastric mucosa, as suggested by previous in vitro studies, ${ }^{17} \mathrm{IL}-8$ could at least in part be responsible for the neutrophil chemotactic properties of the gastric juice of patients with normal mucosa.

The functional importance of IL-8 expression in the gastroduodenal epithelium requires further investigation. There is no neutrophil infiltration in histologically normal gastric mucosa, suggesting that either IL-8 is not secreted, or secreted luminally under normal physiological conditions, or that physiological antagonists are present. Studies on the gastric juice of histologically normal, $H$ pylori negative subjects should clarify whether active luminal secretion of IL-8 occurs in vivo. Recent studies have shown that gastric epithelial cell lines secrete immunologically and biologically active IL-8 in vitro. ${ }^{243}$ Whatever the mechanisms, the increased expression of $\mathrm{IL}-8$ in gastritis is likely to exceed the threshold required for neutrophil infiltration.

Malignant neoplasms are frequently accompanied by inflammatory cell infiltrates and tumour cell lines can secrete cellular chemotactic factors. ${ }^{18-24}$ The observation, therefore, that intestinal and diffuse gastric carcinoma cells expressed IL-8 in vivo and that both IL-8 mRNA and immunoreactive IL-8 were found constitutively in gastric cancer cell lines is of particular interest. Although transitional and renal carcinoma cell lines have recently been shown to express IL-8 in response to IL-1 $\beta$ and TNFa stimulation, constitutive expression was observed in only one out of 10 cell lines tested. ${ }^{20}$ It was proposed that the secretion of IL- 8 by malignant cells could account for inflammation associated with some neoplasms. ${ }^{20}$ There is increasing evidence that pro-inflammatory cytokines have major physiological effects on metabolism, including muscle protein loss, lipolysis, enhancing gluconeogenesis and modifying trace element metabolism. ${ }^{44}$ Apart from potentially inducing peritumoural inflammatory cell infiltrates, therefore, the active secretion of IL- 8 by carcinoma cells could account for some of the paraneoplastic physiological 
disturbances associated with advanced neoplastic disease.

We thank the staff of the Gastroenterology Department of S James's University Hospital for their cooperation, Jane Oakes for expert technical advice, and Wendy Haskell for assistance with the PCR. This study was undertaken with the financial support of Airedale Hospital Trust and St James's University Hospital Trust.

1 Matsushima $\mathrm{K}$, Morishita $\mathrm{K}$, Yoshimura $\mathrm{T}$, et al. Molecular cloning of human monocyte-derived neutrophil chemotactic factor (MDNCF) and induction of MDNCF by interleukin- 1 and tumour necrosis factor. $\mathscr{f}$ Exp Med 1988;167:1883-93.

2 Lindley I, Aschauer H, Seifert JM, et al. Synthesis and expression in Escherichia coli of the gene encoding monocyte-derived neutrophil-activating factor: biological equivalence between natural and recombinant trophil-activating factor. Proc Natl Acad Sci USA 1988; 85:9199-203.

3 Matsushima K, Oppenheim J. Interleukin 8 and MCAF novel inflammatory cytokines inducible by IL-1 and novel inflammatory cytoki

4 Oppenheim J, Zachariae COC, Mukaiada N, Matsushima K. Properties of the novel proinflammatory supergene intercrine cytokine family. Ann Rev Immunol 1991;9:617-48

5 Baggiolini M, Walz A, Kunkel SL. Neutrophil-activating peptide-1/interleukin 8 , a novel cytokine that activates neutrophils. $\mathcal{F}$ Clin Invest 1989;84:1045-9.

6 Schroder JM, Young J, Gregory H, Christophers E. Aminoacid sequence characterization of two structurally related neutrophil activating peptides obtained from lesional psoriatic scales. $\mathcal{f}$ Invest Dermatol 1989;92: lesional

7 Mahida YR, Ceska M, Effenberg F, Kurlak L, Lindley I, Hawkey CJ. Enhanced synthesis of neutrophil-activating peptide-1/interleukin-8 in active ulcerative colitis. Clin Sci 1992;82:273-5.

8 Peichl P, Ceska M, Effenberger F, Haberhauer G, Broel $\mathrm{H}$, Lindley IJD. Presence of NAP/IL-8 in synovial fluids indicates a possible pathogenic role in rheumatoid arthritis. Scand F Immunol 1991;34:333-9.

9 Brennan FM, Zachariae COC, Larsen CG, et al. Detection of interleukin 8 biological activity in synovial fluids from patients with rheumatoid arthritis and production of interleukin $8 \mathrm{mRNA}$ by isolated synovial cells. Eur $\mathcal{F}$ Immunol 1990;20:2141-4.

10 Seitz M, Dewald B, Gerber N, Baggiolini M. Enhanced production of neutrophil-activating peptide-1/interleukin-8 in rheumatoid arthritis. $\mathcal{F}$ Clin Invest 1991;87: 463-9.

11 Rot A. Some aspects of NAP-1 pathophysiology; lung damage caused by a blood-borne cytokine. In: Westwick $\mathrm{J}$, Lindley IJD, Kunkel SL, eds. Advances in experimental medicine and biology. Vol 305. New York: Plenum Press, 1991:127-35.

12 Dixon MF. Helicobacter pylori and peptic ulceration: histopathological aspects. F Gastroenterol Hepatol 1991;6: 125-30.

13 Graham DY. Campylobacter pylori and peptic ulcer disease. Gastroenterology 1989;96:615-25.

14 Wallace JL, Keenan CM, Granger DN. Gastric ulceration induced by nonsteroidal anti-inflammatory drugs is a neutrophil-dependent process. Am F Physiol 1990;259: G462-7.

15 Wallace JL, McKnight GW, Arfors KE. A monoclona antibody against the CD18 leucocyte adhesion molecule prevents indomethacin-induced gastric damage in the rabbit. Gastroenterology 1991;100:878-83.

16 Weiss SJ. Tissue destruction by neutrophils. $N$ Engl $f$ Med 1989;320:365-76.

17 Crabtree JE, Peichl P, Wyatt JI, Stachl U, Lindley IJD. Gastric interleukin-8 and IgA IL-8 autoantibodies in Helicobacter pylori infection. Scand $\mathcal{f}$ Immunol 1993;37: 65-70.

18 Suzuli K, Miyasaka H, Ota $\mathrm{H}$, et al. Purification and partial primary sequence of a chemotactic protein for polymorphonuclear leukocytes derived from human lung giant cell carcinoma LU65C cells. $f$ Exp Med 1989;169: giant cell car

19 Graves DT, Jiang YL, Williamson MJ, Valente AJ. Identification of monocyte chemotactic activity produced by malignant cells. Science 1989;245:1490-3.
20 Abruzzo LV, Thornton AJ, Liebert $\mathrm{M}$, et al. Cytokineinduced gene expression of interleukin-8 in human transitional cell carcinomas and renal cell carcinomas. $\mathrm{Am} \mathcal{\jmath}$ Pathol 1992;140:365-73.

21 Standiford TJ, Kunkel SL, Basha MA et al. Interleukin-8 gene expression by a pulmonary epithelial cell line. A model for cytokine networks in the lung. $f$ Clin Invest 1990;86:1945-53.

22 Yoshida M, Matsuzaki H, Sakata K. Neutrophil chemotactic factors produced by a cell line from thyroid carcinoma. Cancer Res 1992;52:464-9.

23 Zachariae CO, Threstrup-Pedersen $\mathrm{K}$, Matsushima $\mathrm{K}$. Expression and secretion of chemotactic cytokines by normal human melanocytes and melanoma cells. $\mathcal{F}$ Invest Dermatol 1991;97:593-9.

24 Yasumoto K, Okamoto S, Mukaida N, Murakami S, Mai M, Matsushima K. Tumour necrosis factor $a$ and interferon $\tau$ synergistically induce interleukin-8 production in a human gastric cancer cell line through acting concurrently on AP-1 and NF-kB-like binding sites of th interleukin 8 gene. $\mathcal{F}$ Biol Chem 1992;267:22506-11.

25 Misiewicz JJ, Tytgat GNJ, Goodwin CS, et al. The Sydney system: a new classification of gastritis. Working Party Oxford: Blackwell Scientific Publications, 1990:1-10.

26 Lauren $P$. The two histological main types of gastric carcinoma: diffuse and so-called intestinal-type carcinoma. An attempt at a histo-clinical classification. Acta Pathol Microbiol Scand 1965;64:31-49.

27 Trejdosiewicz LK, Southgate J, Hodges GM, Goodman SL. Microheterogenous expression of peanut agglutininbinding sites in the extracellular matrix of cultured cells. binding sites in the extracellula
Exp Cell Res 1985;156:153-63.

28 Trejdosiewicz LK, Southgate J, Kempshead JT, Hodges GM. Phenotypic analysis of cultured melanoma cells expression of cytokeratin-type intermediate filaments by a human melanoma cell line. Exp Cell Res 1986;164: 388-98.

29 Peichl P, Ceska M, Broell H, Effenberger F, Lindley IJD. Human neutrophil activating peptide/interleukin 8, acts as an autoantigen in rheumatoid arthritis. Ann Rheum Dis 1992;51:19-22.

30 Clayton CL, Wren BW, Mullany P, Topping A Tabaqchali S. Molecular cloning and expression of Campylobacter pylori species-specific antigens in Escherichia coli $\mathrm{K}-12$. Infect Immun 1989;57:623-9.

31 Sekiguchi M, Sakakibara K, Fujii G. Establishment of cultured cell lines derived from a human gastric carcinoma fpn f Exp Med 1978;48:61-8.

32 Hojo J. Establishment of cultured cell lines of human stomach cancer origin and their morphological characteristics. Niigata Igakukai Zasshi 1977;91:737-63.

33 Sambrook J, Fritsch EF, Maniatis T. Molecular cloning-a laboratory manual. 2nd Edn. New York: Cold Spring Harbour Laboratory Press, 1989

34 Thornton AJ, Ham J, Kunkel SL. Kupffer cell-derived cytokines induce the synthesis of a leukocyte chemotactic peptide, interleukin-8, in human hepatoma and pritic peptide, interleukin-8, in human hepatoma and pri-

35 Crabtree JE, Shallcross TM, Heatley RV, Wyatt Ji Mucosal tumour necrosis factor $a$ and interleukin- 6 in patients with Helicobacter pylori associated gastritis. Gut 1991;32:1473-7.

36 Mai UEH, Perez-Perez GI, Wahl LM, Wahl SM, Blase MJ, Smith PD. Soluble surface proteins from Helicobacter pylori activate monocytes/macrophages by lipopolysaccharide-independent mechanism. $f$ Clin Invest 1991;87:894-900.

37 Kozol B, Domanowski A, Jaszewski R, et al. Neutrophil chemotaxis in gastric mucosa. A signal-to-response comparison. Dig Dis Sci 1991;36:1277-80.

38 Mooney C, Keenan J, Munster D, et al. Neutrophil activation by Helicobacter pylori. Gut 1991;32:853-7.

39 Mai UEH, Perez-Perez GI, Allen JB, Wahl SM, Blase MJ, Smith PD. Surface proteins from Helicobacter pylori exhibit chemotactic activity for human leukocytes and are present in gastric mucosa. f Exp Med 1992;175:517-25.

40 Denizot Y, Sobhani I, Rambaud JC, Lewin M, Thomas $\mathrm{Y}$, Benveniste J. Paf-acether synthesis by Helicobacter pylori. Gut 1990;31:1242-5.

41 Nielsen H, Andersen LP. Chemotactic activity of Helicobacter pylori sonicate for human polymorphonuclear leucoytes and monocytes. Gut 1992;33:738-42.

42 Craig PM, Territo MC, Karnes WE, Walsh JH. Helicobacter pylori secretes a chemotactic factor for monocytes and neutrophils. Gut 1992;33:1020-3.

43 Plusa S, Farmery S, Peichl P, Lindley IID, Primrose IN, Crabtree JE. Secretion of immunologically and biologically active interleukin-8 by a gastric epithelial cell line. Gut 1993;34:suppl 4, S15.

44 Grimble RF. Nutrition and cytokine action. Nutrition Res Rev 1990;3:193-210. 